DOI: https://doi.org/ 10.20493/birtop.943084

Makale Türü: Araştırma makalesi

Geliş Tarihi: 26.05.2021

Kabul Tarihi: 18.06.2021
Article Type: Research article Submitted: 26.05 .2021 Accepted: 18.06.2021

Atıf Bilgisi / Reference Information

İNCE, F., (2021). II. Haçlı Seferi ve I. Manuel Komnenos Dönemi Bizans-Haçlı İlişkileri, Birey ve Toplum Sosyal Bilimler Dergisi, 11 (1), 73-96.

\title{
II. HAÇLI SEFERİ VE I. MANUEL KOMNENOS DÖNEMİ BİZANS-HAÇLI İLIŞKİLERİ
}

\section{BYZANTINE-CRUSADER RELATIONS IN THE SECOND CRUSADE AND THE FIRST MANUEL KOMNENOS PERIOD}

\author{
Fatma İNCE \\ Doç. Dr., İnönü Üniversitesi Fen-Edebiyat Fakültesi, Tarih Bölümü \\ Assoc. Dr., İnönü University, Faculty of Arts and Sciences, Department of History \\ Eposta: fatma.ince@inonu.edu.tr \\ ORCID: https://orcid.org/0000-0003-4579-6703
}

\section{Öz}

1096 tarihinde başlayan haçlı seferlerinin, başlangıç sebepleri dini duygulara bağlanmaktadır. Bir taraftan Türkiye Selçuklu Devleti, diğer taraftan ise Çaka Bey ve Peçenekler ile mücadele eden Bizans Devleti oldukça zor bir durumda kalmıştı. Bundan dolayı da batıdan yardım istemek zorunda kaldı. Bu dönemde Avrupa'nın da ekonomik, siyasi ve sosyal anlamda oldukça zor bir durumda olduğunu görmekteyiz. Bundan dolayı batılılar, Bizanslılardan gelen yardım teklifini hemen kabul edeceklerdir. Bizanslılar, haçlılardan yardım talep ederken, onlardan paralı askerler olarak faydalanabileceklerini ve bu sayede de Türklere karşı kaybetmiş oldukları toprakları yeniden 
ele geçirebileceklerini düşünmüşlerdir. Ancak zaman ilerledikçe görülecektir ki, sözde dindaşlarını kurtarmak için yola çıkan haçlılar, aslında doğunun zenginliklerini elde etmek ve ele geçirmiş oldukları bölgelere yerleşmek için Bizans Devleti’nin yardım talebine olumlu yanıt vermişlerdir. Daha ilk seferden itibaren haçlıların yolları üzerinde bulunan bölgelerde çıkarmış oldukları huzursuzluklar, vasallık yemini etme konusunda çıkarmış oldukları zorluklar gibi sebepler dolayısıyla Bizans Devleti’nde haçlılara karşı bir ön yargının meydana gelmesine sebebiyet vermiştir. Bundan dolayı da II. Haçlı Seferi’nin düzenlenmesine sıcak bakılmayacaktır. Bu çalışmada II. Haçlı Seferi esnasında Bizans Devleti ve haçlılar arasındaki ilişkiler incelenecektir.

Anahtar Kelimeler: Bizans, Türkiye Selçuklu Devleti, Haçlı Seferleri, Haçlilar.

\begin{abstract}
The initial reasons for the crusades, which started in 1096, are attributed to religious feelings. On one hand, the Seljuk State of Turkey and on the other hand, the Byzantine State, which struggled with ÇakaBey and the Pechenegs, was in a very difficult situation. Therefore, he had to seek help from the west. In this period, we see that Europe is economically, politically and socially in a very difficult situation. Therefore, the westerners will immediately accept the offer of help from the Byzantines. While the Byzantines were asking for help from the crusaders, they thought that they could use them as mercenaries and thus recapture the lands they had lost against the Turks. However, time it would be seen that the crusaders, who set out to save their so-called coreligionists, actually responded positively to the Byzantine State's request for help in order to obtain the riches of the east and settle in the regions they had captured. From the very first time, the crusaders caused a prejudice against the crusaders in the Byzantine State due to the reasons such as the unrest in the regions on their way and the difficulties they had in taking the oath of vassalage. Therefore, organizing the II. Crusade would not be
\end{abstract}


welcomed. In this study, the relations between the Byzantine State and the crusaders during the II. Crusades will be examined.

Key Words: Byzantium, Seljuk State of Turkey, Crusades, Crusaders.

\section{GİRIŞ}

Yaklaşık iki yüz yıllık bir süreyi kapsayan haçlı seferleri 1096-1291 yılları arasında gerçekleşmiştir. Bu seferlerin başlama sebebi, Bizans’in batıdan, Türklere karşı yardım talep etmesidir. Nitekim bu dönemde, Bizans Devleti, Selçukluların topraklarına düzenledikleri akınlardan ve Anadolu'da hızla ilerlemesinden rahatsızlık duyuyordu. Üstelik Selçuklular ile tek başına mücadele edecek güçte de değillerdi. Ancak Bizans Devletỉnin uğraştığı tek mesele Selçuklular değildi. Bizans Devleti, Peçenekler ve Çaka Bey ${ }^{1}$ tarafından da tehdit edilmekteydi. Batı, Bizans'in yardım teklifini hemen kabul etmiştir. Sefer çağrısını ilk dillendiren kişi Papa II. Urban (1088-1099), olacaktır. Ancak Papa II. Urban'in (10881099), ClermontKonsili’nde yapmış olduğu konuşma istenilen etkiyi yaratmayınca bu defa devreye Keşiş Pierre L'Ermitte(1050-1115) girdi. Pierre L'Ermitte (1050-1115) bütün Fransa'yı gezerek, halkı yapmış olduğu ateşli konuşmalar ile galeyana getirdi. İlk haçlı seferi, yapılan bu çağrılar neticesinde 1096 tarihinde gerçekleşti. Haçlılar, bu seferi sözde

1 Türk denizciliğinin atası olarak kabul edilen Çaka Bey, Türk tarihinde ilk defa tersane inşa etmiş ve kendisine ait güçlü bir donanma meydana getirmiştir. Bu donanma sayesinde de Adalar Denizi sahillerinde fetihler yapmış, İzmir ve civarı ile Adalar Denizi’nde ilk Türk yerleşimini sağlamıştır. Türkler, deniz kültürüne uzak bir millettir. Ancak Çaka Bey sayesinde köklü bir deniz kültürüne sahip Bizans karşısında onunla yarışabilecek bir seviyeye yükselmiştir. Bu da bize Çaka Bey’in teşkilatçılık özelliğini göstermektedir. Çaka Bey’in asıl amacı, İstanbul'u ele geçirmektir. Aslında bu hedefini gerçekleştirmek için uyguladığı politikaları değerlendirdiğimizde onun öngörüsünün ne kadar kuvvetli olduğuna da şahit oluruz. Nitekim, Çaka Bey, İstanbul'u alabilmek için Balkanlardaki Peçenekleri kullanmaya çalışmış, Türkiye Selçuklu Sultanı I. Kılıç Arslan'a kızını vererek, onunla akrabalık bağı kurmuş, Rumeli'ye asker çıkarmış ve Bizans'ı karadan da sıkıştırmak için çok ciddi adımlar atmıştır. Ancak ne yazık ki Çaka Bey, bir başka Türk hükümdarı I. Kılıç Arslan öldürülecek ve İstanbul'u alma hayalleri de bu yüzden yarım kalacaktır. Onun gerçekleştirmek istediği bu fethi 360 yıl sonra başka bir Türk hükümdarı gerçekleştirecektir. Ayrıntılı bilgi için bkz. (Baykara, 1974, s.8, Kafesoğlu, 1984, s.55-60, Alptekin, II, 1987, s.476-480, İlgürel, 1993, s.186188, Anna Komnena, 1996, Ayönü, 2009, s.1-8). 
dindaşlarını kurtarmak için düzenliyordu. Ancak ilk haçlı seferinin düzenlendiği dönemde Avrupa’nın yaşamış olduğu sosyal, siyasi ve ekonomik sıkıntılar göz önüne alındığında haçlıların asıl niyetinin doğunun zenginliklerini ele geçirmek olduğu da kolayca anlaşılabilir. (Ordericus, 1853, s.63-64, Duncalf, 1969, s.230-234, Charanis, 1973, s.29, Lilie, 1993, s.1, Anna Komnena, 1996, s.30, Demirkent, 1996, s.525-526, Demirkent, 1997, s.11, Demirkent, 1998, s.1-14, Runciman 2002, s.214, Holt, 2003, s.18-19, Turan, 2004, 128, Somerville, 2011, s.15-16, 25, Frankopan, 2012, s.102-103, Lemerle, 2013, 111-112, Kanat\&Burçak, 2013, s.10, Usta, 2016, s.46, Arslan\&Genç, 2017, s.232, 41-45, Koca, 2017, s.17, Kesik, 2018, s.14).

Bizanslılar, batıdan yardım isterken, Türklere karşı onlardan paralı asker olarak yararlanabilmekti. Ancak haçlı seferi ilerledikçe, Bizans, hem haçlıların güzergahları üzerinde bulunan yerlere büyük zarar vermeleri, hem de ele geçirdikleri yerleri Bizans ile daha önceden yapmış oldukları anlaşma gereğince Bizans'a teslim etmeyip, buralarda kontluklar kurmaları ve yerleşmeleri dolayısıyla büyük bir hayal kırıklığına uğramıştır. (Oldenburg, 1996, s.61, Gölgesiz\& Karaca, 2012, s.141-153, Kaleli, 2018, s.1254-1259).

Bizans'in yardım talebi üzerine Papa II. Urban (1088-1099), Clermont’ta bir konsil toplamıştır. Bu konsil, 18-28 Kasım 1095 tarihleri arasında gerçekleşmiştir. Konsile üç yüze yakın din adamı katılacaktır. Konsilde sadece haçlı seferleri çağrısı yapılmamıştır. Burada bir takım genel sorunlar da çözüme kavuşturulacaktır: din adamlarının siyasi iktidarlar tarafından atanması, din adamlarının para karşılığında makam elde etmeleri ve papazların evlenmeleri yönünde kararlar alınacaktır. Aynı zamanda bu toplantı esnasında, Kral Philippe (1059-1108), zina suçu yüzünden aforoz edilmiştir. Papa II. Urban (1088-1099), 27 Kasım günü önemli haberler vereceğini duyurarak, konsilin ilk oturumunu kapayacaktır. Papa, 27 Kasım 1095 tarihinde halka seslenişinde İncil'den alıntılar yaparak, sözlerine başlayacaktır. Ve kendisini dinleyenlere, Tanrı’nın hizmetkârları olarak, iyiliği ve dini yeniden tesis etmeleri gerektiğini vurgulayacaktır. Papa’nın sözlerine İncil'den başlaması halkın dini duygularını perçinlemek istemesinden ve sahip olduğu ana fikre meşruiyet 
alanı oluşturmak istemesindendir. Papa konuşmasında, Tanrı̉nın dostluğu için onu memnun edecek şeylerin yapılması gerektiğinin ve dinsizlere karşı kiliseyi korumanın gerekliliğinin altını çizmiştir. Türklerin Bizans topraklarını ele geçirdiklerini, birçok insanı öldürdüklerini, kiliseleri yıktıklarını, kısacası Tanrı’nın krallığını harap ettiklerini vurgulamıştır. Doğu' daki kardeşlerine yardım için gideceklerin günahlarının affolunacağ 1 ve İsa'nın birer askeri olacaklarını vaazetmiştir. (Runciman, I, 1986, s.83-84, Carnotensis, 2009, s.47-52).

Papa Urban (1088-1099), konuşmasının devamında bunun bir hac yolculuğu olduğunu vurgulayarak, herkesten, yaz başında hareket edecek şekilde kendilerini hazırlamalarını istemiştir. Papa’nın bu sözleri karşısinda halk heyecanlanarak; "Deus Volt" (Tanrı Böyle İstiyor) nidaları atmıştır. II. Urban'ın (1088-1099), vaazını bitirmesinden sonra, kalabalık içinde haçı ilk kabul eden Le Puy Piskoposu Adhemar de Monteil olacaktır. ClermontKonsilinde alınan kararlar, Limoges'ten Flandre'ye tüm haç̧̧lara mektup ile ulaştırılmıştır. Cenova, Bologna, Pisa ve Milona'ya da elçiler gönderilmiştir. İskoçya, Danimarka ve İspanya' dan da birçok insan haçlı yemini etmek için Papa'ya ulaşmışlardır. Çok sayıda meşhur azilzade haçlı ordusuna katılmak için başvurmuş, onların katılımı sefere önemli bir askeri güç sağlamıştır.(Runciman, I, 1986, s.85, Demirkent, 1997, s.5, Kırpık, 2009, s.52).

Haçlı seferleri Papa II. Urban (1088-1099), ve Keşiş Pierre L’Ermitte(1050-1115) sayesinde böylece başlamıştır. Ancak haçlılar, seferin daha ilk anından itibaren güzergahlarıüzerinde bulunan dindaşlarına oldukça büyük zararlar vermişlerdir. Nitekim I. Haçlı Seferi’nin ilk ordusu olan Pierre L'Ermitte(1050-1115) liderliğindeki ordu yollarda birçok tahribat yaptıktan sonra Almanya'nın Verdün, Mainz, Spire ve Worms şehirlerinde ele geçirdikleri üç bin Yahudi'yi hemen öldürdüler. Almanya'daki bu korkunç durumun aynısı haçlıların yolları üzerinde bulunan Bulgar, Sırp ve Macar topraklarında da devam etti. Bulgaristan'da haçlıların yaptığ 1 tahribatı ve katliamı gören Bulgar Piskoposu Teofilart: "Frankların memleketimizden geçmeleri, bizi o derece meşgul ve mütessir etti ki artık kim olduğumuzu bile idrak edemeyecek hale geldik." demektedir. (Kotan, 1974, s.26). 
Aslında Macar Krall, Pierre L'Ermitte'nin(1050-1115) ordusunu büyük bir hoşgörü ile karşılamıştı. Ona elinden geldiğince de yardımda bulunmuştu. Ancak ordu, 20 Haziran'da Semlin'e varınca bu şehrin valisi ordunun düzensizliğinden ve büyüklüğünden ürkerek, onların hareketlerini sınırlamaya çalıştı. Bunun üzerine Pierre L'Ermitte'nin(1050-1115) ordusu da şehrin kalesine saldırdı ve iki taraf arasındaki çatışma esnasında dört bin Macar hayatını kaybetti. Bundan sonra Macar Kralı'nın kendilerinden intikam alacağ 1 düşüncesi ile haçlı ordusu alelacele Sava Nehri’ni geçmeye çalışmıştır.(Kotan, 1974, s.26).

Bizans Valisi Niketas, haçlıları nehri geçiş sırasında kontrol altına almaya uğraştıysa da bu büyük kitle ile baş edemeyeceğini anlayıp, birliklerini Niş’e çekti. Korkuya kapılan Belgrad halkı da şehri boşalttı. Belgrad'a giren haçlılar, burayı yakıp yakıp yıktılar ve 3 Temmuz'da Niş önüne ulaşarak, aynı hareketlerini burada da devam ettirdiler. Ama Niş valisi de boş durmadı ve bütün askerleri ile bunların üzerine yürüdü. Pierre L'Ermitte'nin (1050-1115) ordusu bozguna uğradı ve pek çok kişi hayatını kaybetti. Bizanslıların elinden kurtulanlarsa, ertesi gün bir araya gelerek, yola koyuldular. Bu ordu 1 Ağustos 1096 tarihinde İstanbul'a ulaşmıştır. (Vitalis, 1853, s.74, Anna Komnena, 1996, s.302-303, Aquensis, 2007, s.9, Kirpık, 2009, s.353).

Düzensiz ordunun arkasından yola çıan düzenli ordu da yol boyunca aynı sıkıntıları yaşatmıştır. Bunlar Macar topraklarına geldiklerinde, Macar Kralı bunları ülkesine sokmak istemedi. Çünkü düzensiz haçlı ordusunun Macar topraklarından geçerken yapmış oldukları yağma ve katliam henüz unutulmamıştı. Ancak haçlı liderlerinden Gedofrai de Bouillon, Macar Kralını ikna etmeyi başardı ve ona topraklarında asla bir kargaşaya izin vermeyeceğine dair de teminat verdi. Gedofrai, Macar topraklarında krala verdiği sözü yerine getirdi. Ama Bulgar topraklarına geçilir geçilmez, haçlılar aynen düzensiz ordunun yaptığı gibi yağma ve çapulculuk hareketlerine giriştiler. Gedofrai’ni bu durumu engellemek için yaptığ 1 bütün girişimleri neticesiz kaldı. Sadece Gedofrai liderliğindeki ordu değil diğer iki ordu da yollarda birçok huzursuzluk çıkartarak, İstanbul önlerine vardılar.(Kotan, 1974, s.29-30). 
Bizans Devleti ve haçlılar arasında meydana gelen bir diğer anlaşmazlık ise vasallık yemini meselesidir. Bizans Devleti haçlılardan topraklarına girdikleri ilk andan itibaren bu yemini almak istemiş ancak haçlılar bu yemini etmeye yanaşmamışlardır. Özellikle haçlı liderlerinden Gedofrai de Bouillon, Tankred, Toulese Kontu Raymond gibi liderler, bu vasallık yeminini kesin bir dille reddetmişlerdir. Bunun üzerine I. Aleksios da (1081-1118), onlara yiyecek tedarikini kesmiştir. Gedofrai, bu durum üzerine Hristiyanlar için kutsal gün sayılan Perşembe günü birlikleri ile beraber İstanbul'a saldırdı. Bu durum, Bizanslılara haçl1ların ne kadar güvenilmez olduklarını bir kez daha gösterdi. Sonunda iki taraf arasında yapılan müzakereler neticesinde bir anlaşmaya varılmıştır. Bu anlaşmaya göre; daha önceden Bizans Devleti’ne ait olup, Türkler tarafından alınan yerler, haçlı ordularının buraları ele geçirmeleri durumunda Bizans Devleti'ne iade edilecekti. (Hill, 1951, s.266-267, Hill\&Hill, 1953, s.323-326,).

İki taraf arasındaki ilişkilerin bozulmasına sebebiyet veren bir diğer olay da 1097 tarihinde İznik'in, Bizans Devleti tarafından Türkler ile yapılan gizli müzakereler sonrasında, haçlılardan habersiz bir şekilde alınması sırasında yaşandı. İznik’in alınmasından sonra Bizans İmparatoru Aleksios'un (1081-1118), Türk garnizonuna oldukça iyi davranması da haçlıların Bizans'a karşı olumsuz bir tutum içerisine girmesine sebebiyet verdi. Onlar, Bizans ve Selçuklular arasında gizlice sürdürülen bu müzakerelerin kendilerine karşı hazırlanmış bir plan olduğunu düşündüler. İki taraf arasındaki ilişkiler, haçlıların ettikleri vasallık yemini gereğince Bizans Devleti’ne vermeleri gereken -Antalya gibi- yerleri onlara vermemeleri sebebiyle daha da içinden çıkılmaz bir hal aldı. Bütün bu sebepler dolayısıyla Bizans İmparatoru I. Manuel'in (1143-1180) haçlılara bakışı oldukça olumsuz olacaktır. Onun, haçlıları kendi topraklarından uzak tutmak ve yıldırmak için uyguladığ 1 stratejiler, batılıların gözünde her zaman Hristiyanlığa ihanet eden birisi olarak anılmasına sebebiyet verecektir. 


\section{1- II. Haçlı Seferi ve I. Manuel Komnenos Dönemi Bizans-Haçlı İlişkileri}

1098 tarihinde kurulan Urfa Haçlı Kontluğu, II. Joscelin (1113-1159) döneminden itibaren, İmadeddinZengi'nin $(1128-1146)^{2}$ harekete geçmesi ile beraber oldukça zor bir durumda kalmıştır. Aslında saltanatının ilk yıllarında kontluğunu, Zengi'nin (1128-1146)Suriye bölgesinden ayrılmış olması sebebi ile oldukça rahat bir şekilde idare etmiştir. İmadeddinZengi (1128-1146), birkaç defa Dımaşk şehrini egemenliği altına almaya teşebbüs etmiş ancak haçlı ordularının Dımaşk atabeyine yardım etmeleri sebebi ile bu siyasetini gerçekleştirmeye muvaffak olamamıştır. Bütün çabalarına rağmen,Dımaşk'ı ele geçiremeyen Zengi (1128-1146), adının hutbede okunması ile yetinerek, dikkatini haçl1lar üzerine çevirmiştir. Zaten bu esnada, Urfa Kontluğu'na bağlı süvari birlikleri Rakka, Nusaybin ve Amid'e kadar sokulmuşlar, Mardin civarı ile Harran'ı da tehdit altına almışlardır. Bunun üzerine, Irak Selçuklu Sultanı Mesud, kendisine bağlı Musul atabeyine Urfa'nın fethini emretmiştir. (Demirkent, 1997, s.78-79).

Zengi (1128-1146), uzun zamandır haçlıların kendi aralarındaki ve Bizans Devleti ile olan anlaşmazlıkları yakından takip etmekteydi. Nitekim bu dönemde haçlı kontlarının birbirleri ile arası bozuktu. Aynı

2 İmadeddin Zengi (1128-1146), Zengiler hanedanlığının kurucusudur. İmadeddin, hanedanlığının temellerini Halep ve Musul merkez olmak üzere atmıştır. İmadeddin Zengi (1128-1146), Kasimüddevle Aksungur'un (1087-1094) oğludur. Kasimüddevle Aksungur (1087-1094), Sultan Alparslan (1063-1072) zamanında Selçukluların hizmetine girmiş onun ölümünden sonra ise oğlu Melikşah (1072-1092) tarafından Halep valiliğine getirilmiştir. Melikşah'ın (1072-1092) ölümünden sonra ise Tutuş (1094-1095)-Berkyaruk (1092-1104) mücadelesinde Berkyaruk (1092-1104) tarafında yer almış, bunun için de Tutuş ile mücadele etmek zorunda kalmıştır ve bu mücadelede de hayatını kaybetmiştir. Aksungur öldüğü zaman o esnada yedi yaşında bulunan tek oğlu İmadeddin Zengi (1128-1146) babasının ölümünden sonra hem Selçuklu sultanı hem de Halep emiri tarafından koruyup kollanmıştır. 1096 senesinde Kerboğa, Sultan Berkyaruk (1092-1104) adına Musul'a el koymuştur. Musul'un Berkyaruk'un (1092-1104) eline geçmesinden sonra İmadeddin Zengi de(1128-1146), gulamları ile birlikte bu şehre getirilmiş ve kendisine şehirden iktalar verilmiştir. İmadeddin Zengi(1128-1146), burada Musul Valisi Mevdud tarafından haçlılara karşı düzenlenen seferlere katılmış ve bu seferlerde kazandığı başarılar ona büyük bir şöhret kazandırmıştır. (Bezer, IV, 2002, s.803). 
zamanda Bizans Devleti ve haçlılar arasındaki ilişkiler de oldukça kötüydü. Kudüs Krallığı ise bu dönemde etkili bir yardım gönderebilecek durumda değildi. Ancak bütün bu avantajlara rağmen Urfa çok güçlü surlara sahipti. İmadeddinZengi (1128-1146), II. Joscelin'in şehirde olmadığı bir sırada Urfa'yı kuşatmaya karar verdi. Beklediği an da pek gecikmedi. Artuklu Hükümdarı Kara Arslan’’n yardım çağrısını kabul eden Joscelin'in (1113-1159) şehirden uzaklaştırıldığı kendisine bildirilince derhal harekete geçti. (Sevim\&Merçil, 1995, s.256, Demirkent, 1997, s.78-79).

İmadeddin Zengi (1128-1146), Urfa önüne ulaştığında önce İslami kaidelere uygun olarak, şehre haber göndererek, kan dökülmesini ve şehrin harap olmasını önlemek için teslim olmalarını talep etmiştir. II. Joscelin'in şehirden ayrılışı esnasında, şehirde yüksek rütbeli bir asker olmamasından dolayı müdafaa işlerini şehrin Latin Başpiskoposu II. Hugue'ye birakmıştı. Hugue, İmadeddinZengi’nin teslim teklifini kabul etmemiştir. Bunun üzerine şehre taarruza başlayan Türk birlikleri, 24 Kasım 1144 günü şehirdeki savunmayı kırarak, Urfa’yı ele geçirmişlerdir. Böylece Urfa yeniden Türk-İslam dünyasına kazandırılmıştır. (Demirkent, 1994, s.145, Demirkent, 1997, s.78-79).

Urfa, jeopolitik konumu itibariyle oldukça önemli bir bölgeydi. Çünkü burası Horasan'dan gelen Türkmen akışının sağlandığı yerdi. Dolayısıyla, Urfa'nın İmadeddin (1128-1146) tarafından fethedilmesi, Avrupa'da bir yankı uyandırmıştır. Urfa’nın, İmadeddin Zengi (1128-1146) tarafından fethedilmesinden sadece üç yıl sonra haçlılar, Urfa’nın intikamını almak için yeni bir sefer düzenlemeye karar vermişlerdir. Bu yeni haçlı seferinin düzenlenmesinde özellikle Kudüs Kraliçesi Melisende ve Antakya Prinkepsi Raimond'un batıdan yardım istemelerinin de oldukça büyük bir payı vardır. Bütün bunların neticesinde, Papa III. Eugenius, hemen işe girişti ve Fransa Kralı VII. Louis (1137-1180) ve Alman Kralı III. Konrad (1138-1152) ile iletişime geçerek, yeni bir seferin düzenlenmesi için çalışmalara başladı. (Michaud, 1853, s.329, Berry, 1969, s.466,).

$\mathrm{Bu}$ seferin en ilgi çeken yanlarından birisi Papa III. Eugenius'un seferle alakalı yayınlamış olduğu fermandır. Bu fermanda Papa, Urfa'dan 
hiç bahsetmemektedir. Bu durum bize batının artık Urfa' dan tamamen umudunu kesmiş olduğunun bir göstergesidir. Yeni sefere çıkılmasındaki amaç ise Kudüs ve Antakya’nın da Türklerin eline geçmesini önlemektir. (Runciman, III., 1986, s.214).

Birinci seferde haçlı seferi çağrısını Papa II. Urban (1088-1099), yapmıştı. Bu kez bu görevi, Papa III. Eugenius üstlenecektir. Keşiş Pierre L'Ermitte'nin (1050-1115) yerinde ise papanın yardımcısı olarak bu kez Fransızların başrahibi Bernard'ı görmekteyiz. Papa III. Eugenius tarafından yeni bir haçlı seferi için ilk çağrı, 1 Aralık 1145 tarihinde gerçekleşecektir. Ancak bu çağrı istenilen yankıyı uyandırmayacaktır. Çünkü, bu dönemde, ilk haçlı seferinin üzerinden kırk yıl gibi bir zaman geçmişti. Bu süre içerisinde de batının Kudüs'e olan ilgisi ve şevki büyük ölçüde azalmıştı. Yeni bir haçlı seferi için bu ilgi ve şevkin yeniden canlandırılması gerekmekteydi. Bundan dolayı Papa III. Eugenius, ilk bildiride bir takım değişiklikler yaparak 1 Mart 1146 tarihinde yeniden yayınlamıştır. (Phillips, 1996, s.78, Constable, 2008, s.229-231).

Eugenius, yeniden düzenlediği bu belgede, I. Haçlı Seferi’nde, Papa II. Urban'ın (1088-1099), kullanmış olduğu kullanmış olduğu dini motiflerin aynen tekrar edildiğini görmekteyiz. Buna göre; sefere katılacakların günahları affolunacak, malları ve aileleri korunacaktı. Fransa Kralı VII. Louis (1137-1180) bu çağrıyı çok büyük bir şevkle destekledi. Ancak Louis, piskopos ve asillerden istediği yardımı göremedi. Bunun üzerine Louis, Fransa'da sözü kendisinden daha geçerli olan başrahip Bernard de Clairvaux ile temasa geçti ve ondan bu konuda yardım istedi. (Runciman, II., 1986, s.209, Demirkent, 1997, s.101, Kesik, 2018, s.165).

Bernard, haçlı seferleri için ilk konuşmasını 31 Mart 1146 tarihinde Vezelay'da yaptı. Onun vaaz edeceği haberi üzerine öylesine çok insan buraya koşup gelmişti ki, Bernard bu kalabalık kitleye ancakkasabanın dışında bir tarlada kurulan kürsüden hitap edebildi. Konuşması kısa sürede dinleyicileri adeta çılgına döndürdü. Herkes: "Bize haç verin, haç verin.” diyerek, çığlıklar atarak kürsüye koştular. Bernard'in önceden elbiselere dikmek üzere hazırlattığı haçlar çabucak tükendi. O da tam 
bir gösteri havasıyla yeni haçlar yapılması için kendi cübbesini yırtıp, parçaladı. (Demirkent, 1997, s.101-102, Altan, 2003, s.16).

Haçı ilk kabul eden Kral Louis oldu. Pekçok şövalye ve ileri gelen de Kral Louis'i (1137-1180) örnek aldı. Kralın kardeşi, dayısı, Flanddre, Toulouse, Nevers, ChampagneKontları ve birçok piskopos da sefere katılmayı kabul etti. Basit halk tabakası, asillerden daha fazla heyecanlanmıştı. Bernard, Papa'ya yazdığı mektupta şöyle diyordu: "Siz emrettiniz, ben itaat ettim. Ve emri verenin kudreti benim itaatimi verimli kıldı. Haçlı seferini bildirdiğim ve konuştuğum her yerde haçlıların sayısı sayılamayacak kadar arttı. Şehirler ve kaleler boş kaldı. Şimdi yedi kadına ancak bir erkek düşüyor. Her yerde kocaları hâlâ hayatta olan dullar var." (Demirkent, 1997, s.101-102).

\section{2- II. Haçlı Seferi Ordularının Yola Çıkması Ve Bizans İmparatoru Manuel'in Haçlılara Bakışı}

Bizans İmparatoru Manuel (1143-1180),yeni bir seferin düzenlenmesine sıcak bakmıyordu. Çünkü I. Haçlı Seferi’nde bu konuda kötü bir tecrübe yaşamıştı. Bizans Devleti, I. Haçlı Seferi öncesinde batılılardan yardım talep ederken, onlardan paralı asker olarak yararlanma düşüncesindeydi. Aynı zamanda onlar sayesinde, Türkler tarafından ele geçirilen toprakların haçlılar sayesinde tekrar Bizans’a kazandırılacağını sanıyordu. Ancak işler hiç de Bizanslıların istedikleri gibi olmadı. Haçlılar, bölgeye geçici olarak değil kalıcı olarak gelmişlerdi. Birinci sefer sonrası kurulan haçlı kontlukları da bunun göstergesidir. Üstelik haçlılar, Bizans arazisinde de birçok huzursuzluğa sebep olmuşlardı. Bunun için Bizans İmparatoru Manuel (1143-1180), ikinci bir seferi gereksiz görüyordu. (Öngül, 2007, s.58).

Bizans Devleti, II. Haçlı Seferi öncesinde, Türkiye Selçuklu Devleti ile mücadele etmekteydi. Üstelik bu mücadele esnasında Alman İmparatoru III. Konrad'dan da (1138-1152) destek alıyordu. Türklere karşı tek başına mücadele edebilecek güçteyken, yeni bir seferin düzenlenmesi Bizans Devleti açısından olumlu bir durum değildi. Bizans İmparatoru Manuel (1143-1180), yeni bir haçlı seferinin düzenleneceğini haber alınca, 
mecburen Türkiye Selçuklu Sultanı Mesud (1116-1155) ile anlaşma yapmak zorunda kalmıştır. Aslında İmparatorun bu anlaşmayı yapmasındaki amacı, doğu sınırlarının güvenliğini sağlamaktı. Nitekim, Bizans Devleti,I. Haçlı seferi esnasında haçlıların kendi topraklarında yaratacağı tehlikeyi deneyimlemişti. Dolayısıyla Manuel (1143-1180), Türkiye Selçuklu Devleti ile anlaşma yapmasaydı hem doğu sınırlarında Türkiye Selçukluları ile hem de batıda haçlılar ile mücadele etmek zorunda kalabilirdi. Ancak Manuel (1143-1180), Türkler ile yapmış olduğu bu anlaşma nedeniyle her zaman haçlılar tarafından ihanetle suçlanmıştır. (Runciman, II, 1986, s.220, Magdalino, 1993, s.42, Altan, 2003, s.41-43, Ayönü, 2014, s.132-137).

Yeni bir seferin başlamasının Manuel açısından bir başka önemli sıkıntısı ise Alman İmparatoru Konrad (1138-1152) ile yapmış olduğu anlaşmanın tehlikeye girmesidir. Çünkü Alman İmparatoru Konrad da (1138-1152) bu yeni düzenlenecek sefere katılmaya karar vermiştir. (Bailly, 1970, 337). Ancak bütün bu olumsuz durumlara rağmen Manuel'in haçlılar ile anlaşarak, onlara yardım etmekten başka çaresi de yoktu. Manuel (1143-1180), kendisine düzenlenecek bu yeni seferle alakalı sürekli mektuplar yollayan Papa ve Fransa Kralına olumlu yanıtlar verdi. Ancak Manuel'in de (1143-1180) haçlılardan bir takım istekleri vardı: ele geçirilen araziler, Bizans'a verilecek ve İmparatora da sadakat yemini edeceklerdi. (Runciman, II, 1986, s.216, Altan, 2003, s.36-37,).

II. Haçlı Seferi orduları, Alman ve Fransız Kralları nezdinde 1147 tarihinde yola çıtılar. Manuel (1143-1180) Almanlara gönderdiği elçiler vasıtasıyla, onlara herhangi bir karışıklık çıkarmamaları durumunda her türlü desteğin verileceğini belirtmiştir. Manuel (1143-1180) haçlıların güzergâhlarında bulunan bölgelere onların iaşelerinin karşılanması için pazarlar kurdurdu. Ancak buna rağmen açılan Pazar yerlerini yeterli bulmayan haçlılar Bizans köylerini yağmalamışlardır. (Berry, 1969, s.485-490).

Alman ordusu, İstanbul'a ulaştıktan sonra Manuel (1143-1180) onları hızla Anadolu'ya geçirdi. Aynı zamanda, Konrad'a (1138-1152) Türkler ile savaşa girmemesini ve Bizans arazisinden geçerek, Antalya’ya gitmesini 
öğütledi. Ancak Konrad (1138-1152), bunu dikkate almadı. Konrad (11381152), Bizans arazisinde oldukça rahattı. Ancak Selçuklu topraklarına girdiği andan itibaren Alman ordusu açısından zorluklar da başladı. Özellikle Sultan Mesud'un(1116-1155) onları yakından takip ederek, artçılarına saldırıp, ağır kayıplar verdirmesi Alman haçlılarının bütün nizamını alt-üst etti. Yine Bizans tarafından Alman İmparatoru’na verilen kılavuzlar da kaçmışlardı. 26 Ekim 1147 tarihine gelindiğinde, Eskişehir yakınlarındaki Sarı Su Irmağı kıyısında dinlenen Alman haçlı ordusuna saldıran Türkler, onların neredeyse tamamına yakınını yok ettiler. (Gregory Abu'l-Farac, 1987, s.384-385, Ayan, 1994, s.44, Altan, 2003, s.64-65, Madden, 2004, s.62 Çalışır, 2018, s.35).

Fransız haçlı ordusuna gelince, İmparator Manuel'in (1143-1180), Fransız Kralı VII. Louis'e de (1137-1180) elçiler göndermiş ve onlardan hem kendisine vasallık yemini etmelerini ve yolda herhangi bir huzursuzluk çıkartmayacaklarına dair söz vermelerini hem de Bizans'a ait olan bir toprak ele geçirildiği taktirde buranın Bizans'a verilmesini istemiştir. Bu şartlar, Fransızlar tarafından kabul edilince Manuel de (1143-1180) Fransızlara ikmal ve iaşe konusunda yardımcı olacağına dair söz vermiştir. Ancak Bizans Devleti, hem I. Haçlı Seferi'nde yaşanan olumsuzluklardan hem de II. Haçlı Seferi'nde Almanların çıkartmış oldukları karışıklıklardan dolayı Niş-Edirne hattından İstanbul'a doğru ilerlemekte olan Fransızlara karşı oldukça sert bir tutum sergilemişlerdir. Haçlıları, güzergâhları üzerinde bulunan hiçbir şehre sokmayan Bizans Devleti, iaşe konusunda da onlara zorluk çıkarmışlardır. (Odo de Deuil, 1948, s.41).

Bizans İmparatoru Manuel (1143-1180), İstanbul önlerine varan Fransızları, biran önce İstanbul'dan uzaklaştırmak istiyordu. Bunun için İmparator Manuel (1143-1180), bilinçli olarak Almanların, Türklere karşı yapmış oldukları mücadelede başarılar kazandıklarını, hatta hiçbir kayba uğramadan Türklerden 14.000 kişiyi öldürdüklerini söyledi. Bunu duyan Fransızlar, biran önce Almanlara yetişmek istediler. Çünkü Almanları kıskanıyorlardı. Ancak Louis (1137-1180), İznik yakınlarına ulaştı̆̆ında, durumun hiç de kendisine anlatıldığg gibi olmadığını gördü. 
Konrad'in (1138-1152) yeğeni Friedrich von Schwaben, Kral Louis'in (11371180) ordugâhına gelerek, Alman İmparatoru Konrad'ın (1138-1152) başına gelenler konusunda Louis'e bilgi vermiştir. Louis (1137-1180), derhal maiyeti ile birlikte, Kral Konrad'in (1138-1152) yanına gitti. İki kral durum değerlendirmesi yaptıktan sonra Louis' in (1137-1180) yola devam etmesini, Konrad'ın (1138-1152) İznik'e giderek, erzak temin etmesini ve daha sonra da Louis'e yetişmesini kararlaştırdılar. (Kesik, s.2003, s.88).

Louis (1137-1180), Ulubat dolaylarında karargâhını kurdu ve Konrad'in (1138-1152) gelmesini beklemeye başladı. Konrad'in ordusu ise iaşe hazırlığ 1 yapmak için harekete geçti. Ancak bu amaçla köylere baskınlar yaptıkları için Bizans kuvvetleri tarafından hücuma uğradılar. Konrad, Bizans kuvvetleri karşısında zor durumda kalınca, Louis'e (1137-1180) başvurarak, ondan yardım istedi. Louis (1137-1180), Soissons Kontu kumandasındaki bir Fransız birliğini Almanların yardımına gönderdi. Konrad (1138-1152) ve ordudan geriye kalanlar kurtarıldı. Konrad (1138-1152),Louis'in (1137-1180) kampına götürüldü ve bundan sonra Fransız ordusu himayesinde yola devam etmek istediğini bildirdi. (Kesik, 2003, s.88-89).

Bunun üzerine, Louis (1137-1180) önderliğinde harekete geçen haçlı birlikleri, Selçuklu topraklarına girmekten kaçınarak, Bizans arazisinden ilerlemiş, önce Edremit arkasından da Bergama yolu ile Efes'e ulaşmışlardır. Kral Konrad (1138-1152), Efes'te hastalandı. Bunun üzerine Manuel (1143-1180), onu alarak İstanbul'a götürdü ve Konrad (1138-1152) ile arasını düzeltmek için de onunla yakından ilgilenerek, tedavi ettirdi. İyileştikten sonra da Konrad'a yeterince para vermiş ve bir Bizans filosu ile onu Filistin'e göndermiştir. ${ }^{3}$

3 Aslında, Fransızların komutası altında yollarına devam eden Alman haçlıları sürekli olarak, Fransızların aşağılayıcı davranışlarına maruz kalmışlardır. Haçlılar, Efes'e vardıklarında Kral Konrad'a (1138-1152), Manuel'in (1143-1180) bir mektubu ulaşacaktır. Bu mektupta Manuel (1143-1180), Konrad'ı (1138-1152) teselli ederek, onu yanına çağırmaktaydı. Zaten Selçuklular karşısında ordusunun büyük bir kısmını kaybeden Konrad'ın (1138-1152) bu mücadelede yer almasının bir anlamı da kalmamıştı. Bunda dolayı da Konrad (1138-1152), hastalığını da bahane ederek, Manuel'in (1143-1180) davetini kabul ederek, haçlı ordusundan ayrılmıştır.( Kesik, 2003, s.90, Venning, 2006, s.482,). 
Manuel (1143-1180), Fransız Kralı Louis'e de (1137-1180) bir mektup yazarak, Türklerin haçlılara karşı büyük ordular hazırladıklarını ve bundan dolayı haçlıların Bizans kalelerine sığınmalarını tavsiye etmiştir. Manuel (1143-1180), bu mektubunda aynı zamanda haçlıların Bizans arazisinde yaratmış oldukları huzursuzluklardan dolayı artık Bizans halkının haçlılara destek vermesinin mümkün olmayacağını ifade etmiştir. Ancak Kral Louis (1137-1180) bu mektupları ciddiye almamıştır. (Berry, 1969, s.497-498, Runciman, II, 1986, s.225).

Manuel (1143-1180) oldukça iyi bir diplomattı. Nitekim o Alman İmparatoru Konrad'ı (1138-1152), İstanbul'a öylesine davet etmiş değildi. Manuel'in (1143-1180) en büyük amacı, Fransız ve Alman krallarını birbirinden ayırmaktır. Bu sayede hem Fransızların gücünü kırmayı hem de Alman Kralı Konrad (1138-1152) ile Sicilya’ya karşı yeniden bir ittifak yapmayı planlamıştır. Manuel (1143-1180), diğer taraftan da Sultan Mesud(1116-1155) ile yaptığ 1 anlaşmaya mümkün mertebe riayet etmeye gayret göstermiştir. Manuel (1143-1180), haçllar ile olan irtibatını da asla kesmemiştir. Çünkü haçlıların, yaşadıkları herhangi bir olumsuzluk karşısında kendisini sorumlu tutmalarından çekinmiştir. (Deuil, 1948, s.109, Odo of Angold, 1997, s.166-167, Altan, 2003, s.82).

Fransız haçlı ordusu, Manuel'den (1143-1180) gelen bu mektuplara hiç itibar etmeden bir süre Efes'te kaldıktan sonra Menderes Vadisi boyunca, Denizli istikametinde ilerlemeye başlamışlardır. Fransızlar, Menderes nehri boyunca ilerlerken, peşlerine takılan Almanların varlıklarından da oldukça rahatsızlık duymuşlardır. 1147 Noel'ini kutlamak için Decervion'da mola verdikleri esnada aniden başlayan şiddetli yağmur, haçlı karargâhına büyük zarar verdi. Bunun yanı sıra, Türkler de haçlı ordusuna taarruzlarda bulunarak, onları oldukça hırpalıyorlardı. Ancak bütün bunlara rağmen, haçlı ordusu sayıca Türklerden üstün oldukları için nehri geçmeyi başardılar. (Demirkent, 1997, s.107).

$\mathrm{Bu}$ olaydan üç gün sonra haçlılar, Denizli'ye ulaştılar. Ancak şehri boş buldular. Şehirde yiyecek kalmamıştı. Bu yürüyüş esnasında yaşanan bütün bu olumsuzluklar dolayısıyla haçlı ordusunun morali de oldukça bozulmuştu. Bölgenin coğrafi şartlarından dolayı kamp kurmak 
imkanı bile bulamıyorlardı. Kamp yeri bulduklarında ise Türkler, haçlı birlikleri arasındaki irtibatsızlıktan ve onların yorgunluklarından faydalanarak, haçlı ordularının büyük bir kısmını yok ettiler. Akşam karanlık çökünceye kadar devam eden bu saldırılardan Kral Louis (11371180) bile canını zorlukla kurtarabildi. (Kesik, 2003, s.94).

Ertesi gün haçlilar yollarına devam ettiler. Ancak orduda nizam ve intizam kalmamıştı. Ayrıca askerler de çok bitkin bir durumdaydı. $\mathrm{Bu}$ şartlar altında düzenlerini bozmayan tek bir grup vardı: Templier Şövalyeleri. Hatta Kral Louis (1137-1180), bu intizamın bütün orduda uygulanabilmesi için Templierlerin lideri Evrard of Barrers'den de yardım istemiştir. Haçlılar, Antalya'ya varıncaya kadar Türkler tarafından oldukça yıpratılmışlardır. Türkler, yol üzerindeki ekinleri ve otları tahrip etmişlerdir. Bundan dolayı da haçlılardan pek çok asker ve hayvan erzak sıkıntısı dolayısıyla yollarda hayatını kaybetmiştir. Haçlılar, Antalya'ya vardıklarında perişan bir vaziyetteydiler. (Kesik, 2003, s.94-95).

Ancak haçlılar, Antalya'da da istediklerini bulamayacaklardır. Çünkü burada yeterli erzak bulunmamaktadır. Bunun üzerine Kral Louis (11371180), maiyeti ile birlikte Antakya'ya gitmeye karar verecektir. Antakya'ya gitmek için en güvenilir yol deniz yoluydu. Haçlılar, gemi temini konusunda Bizanslılardan söz almışlardı. Ancak Bizans tarafından temin edilen gemiler, bütün haççlları taşıyabilecek büyüklükte değildi. Aynı zamanda deniz yolculuğu için ödenecek meblağ da oldukça yüksekti. Bundan dolayı gemilere sadece kral, maiyeti, asiller ve piskoposlar binebildiler. Ordunun büyük bir kısmını teşkil eden yayalar ise Antalya' da bırakıldı. Kral Louis'in (1137-1180), Antalya'dan çıkmasından sonra geride kalan haçlılar, Antalya valisi tarafından şehrin dışına çıkartıldılar. Bir taraftan Bizanslılar tarafından düşmanca hareketlere maruz kalan haçlılar, diğer taraftan çıkarıldıkları kale dışında Türklerin hücumuna uğradılar ve oldukça kötü bir duruma düştüler. Haçlıların düştükleri bu duruma acıyan Türkler, saldırılara son verdiler ve haçlılara yiyecek yardımında bulunarak, yaralılarını da tedavi ettiler. Kaynaklarda bu durumda oldukça etkilenen üç bin Fransız’n Müslüman olduğundan bahsedilmektedir. (Kesik, 2003, s.96, Usta, 2016, s.150). 
Louis (1137-1180), 19 Mart 1148 tarihinde, Antakya'da karaya çıktı. Raymond, bu duruma oldukça sevindi. Çünkü Kral Louis sayesinde sürekli savunma durumunda olduğu Nureddin'e karşı taarruza geçebileceğini, Halep ve Şeyzer gibi bölgeleri ele geçirerek, prinkepslik topraklarını genişletebileceğini umuyordu. Ancak yaşanan gelişmeler, Raymond'un hayal kırıklığı yaşamasına sebebiyet verecektir. Raymond, Nureddin karşısında yaşadığı sıkıntıları Kral Louis (1137-1180) ile birkaç kez paylaşmıştı. Ancak Louis'in asıl hedefi, Kudüs'tü. Üstelik Alman Kralı Konrad'ın da Kudüs'e ulaştığı haberi gelmişti. Kral Louis (1137-1180), Raymond ve Raymond'un yeğeni olan eşi Eleanore'nin bütün ısrarlarına rağmen Antakya'dan ayrıldı ve Kudüs'e gitti. (Demirkent, 1997, s.110-111, Altan, 2003, s.98-99).

Akka'da bir araya gelen haçlılar, bundan sonraki süreçte ne yapılacağı ile alakalı bir toplantı yapmışlardır. Ve neticede Dımaşk üzerine bir sefer yapmaya karar vermişlerdir. Ancak alınan bu karar stratejik bir hatadır. Çünkü Dımaşk, Frankların tek Müslüman müttefikidir. Dımaşk’ın başında bulunan Unur, Nureddin Mahmud b. Zengi ile arasındaki akrabalık bağlarına rağmen Kudüs Krallığı ile dost kalmaya çalışmaktaydı. Unur, haçlı ordularının kendi üzerlerine geldiğini haber alınca Nureddin'den yardım istedi. Unur, Nureddin Mahmud b. Zengi başta olmak üzere Müslümanlardan almış olduğu destek sayesinde haçlıları yenilgiye uğratmayı başarmıştır. Dımaşk başarısızlığı ile birlikte büyük ümitlerle başlayan II. Haçlı Seferi haçlılar açısından tam bir hezimetle neticelenmiştir. (Demirkent, 1997, s.110-111, 115, Altan, 2003, s.117).

\section{SONUÇ}

Birinci Haçlı Seferi’nin düzenlenmesinin görünürdeki sebebi, Bizansinn Türkler karşısında yaşamış olduğu sıkıntılardır. Nitekim ilk haçlı seferinin başladığı dönemde Bizanslılar, bir taraftan Selçuklu Türkleri, bir taraftan Çaka Bey diğer taraftan da Peçeneklerin tehdidi altında bulunmaktaydı. Bütün bu unsurlarla tek başına mücadele edemeyeceğini anlayan Bizans Devleti Batı́dan yardım istemek zorunda kalmıştır. Bizans’’n Batı'dan istediği yardım onlardan paralı asker olarak 
faydalanmak suretiyle, Türklere karşı kaybetmiş olduğu toprakları yeniden ele geçirebilmekti. Ancak bu ilk seferde haçlıların Bizans topraklarında sergilemiş oldukları olumsuz tutumlar, Bizans Devleti’nde haçlılara karşı bir ön yargının oluşmasına sebebiyet vermiştir. Mesela; haçlıların İstanbul önlerine gelinceye kadar yollarda yaratmış oldukları huzursuzluklar, İstanbul önlerine geldiklerinde Bizans İmparatoru’nun haçlılardan istemiş olduğu vasallık yeminini vermek istememeleri, yine iki taraf arasında yapılan anlaşma mucibince Bizans Devletỉne teslim etmeleri gereken toprakları onlara vermemeleri gibi sebepler iki taraf arasındaki ilişkilerin bozulmasına sebebiyet vermiştir. Yine Antakya'da, Urfa'da ve Kudüs'te kurulan haçlı kontlukları da haçlıların Bizans topraklarına dindaşlarını kurtarmak amacıyla değil, Anadolu’ya yerleşmek amacıyla geldiklerini göstermektedir.

İkinci Haçlı Seferi dönemine gelindiğinde ise; Bizans Devleti siyasi olarak güçlenmiş durumdaydı. Türklere ve Sicilyalılara karşı vermiş olduğu mücadelede, Alman Kralı III. Konrad'ın da desteğini alan Bizans İmparatoru Manuel, bu dönemde oldukça rahat bir durumdayd. Ancak 24 Aralık 1144 tarihinde Urfa'nın İmadeddin Zengi tarafından fethedilmesi, Avrupa'da Türklere karşı yeni bir seferin düzenlenmesi fikrini de ortaya çıkardı. Tam bu esnada Türkiye Selçuklu Devleti ile mücadele eden Manuel, yeni bir seferin düzenlenmesi fikrine hiç sıcak bakmamıştır. Bu, pek çok açıdan Bizans Devleti’ne zarar verebilecek bir durumdur. Nitekim, yeni düzenlenecek olan bu sefere Alman İmparatoru Konrad da katılmaya karar vermiştir. Onun bu sefere katılması demek, Almanlar ve Bizans arasında hem Türklere hem de Sicilya'ya karşı yapılan anlaşmanın da yarıda kalması anlamına gelmekteydi. Aynı zamanda, Bizans Devleti, haçlıların ilk seferde yaratmış oldukları olumsuzlukları da henüz unutmuş değillerdi. Bütün bunlardan dolayı, Bizans Devleti yeni bir seferin düzenlenmesini istememekteydi.

Haçlı ordularının yola çıktığını haber alan Manuel, derhal Türkler ile bir anlaşma yapmıştır. Her ne kadar Manuel, haçlıların bu seferine sıcak bakmasa da kendisini ihanetle suçlamalarından korktuğu için onlara yardım edeceğini ifade etmiştir. Ancak Manuel'in de haçlılardan bir takım istekleri vardır: Güzergâhları boyunca herhangi bir karışıklığa 
sebebiyet vermemeleri, vasallık yemini etmeleri ve Bizanslilara ait olan toprakları ele geçirdikleri takdirde, Bizans'a teslim etmeleri. Ancak haçlılar, daha ilk andan itibaren, Bizanslıların bu isteklerini yerine getirmeyeceklerini göstermişlerdir. Yol boyunca huzursuzluk yaratan haçlı birlikleri -özellikle Almanlar- vasallık yemini etme konusunda da İmparator Manuel'e zorluk çıkarmışlardır. Manuel de bu durum karşısında bir takım tedbirler almak mecburiyetinde kalmıştır. Mesela, Bizans halkı, haçlıları kale içlerine sokmamıştır. Kale diplerinde ordugâhlarını kuran haçlılar, iaşe ve ikmal ihtiyaçlarını da Bizans halkının verdikleri kadarıyla karşılamak zorunda kalmışlardır. Haçlıların paralarını da değerlerinin çok altına bozmuşlardır. Bizans İmparatoru Manuel, haçlılara kılavuzlar vermiş, ancak bu kılavuzlar haçlı karargâhından kaçmışlardır. Bütün bunların üzerine Bizans Devleti’nin Türklerle bir anlaşma yaptığının ortaya çıkması da haçlıların Bizans Devleti’nden iyice nefret etmesine sebebiyet vermiştir. Haçlıların Bizans'a karşı duymuş oldukları bu nefret dönemin kaynaklarına da yansımıştır. Mesela Odo de Deuil'in, De Profectiona Ludovici VII in Orientem ve Niketas'in, $O$ City of Byzantium isimli eserlerinde Bizans'in haçlı seferleri esnasında sergilemiş oldukları tutum dolayısıyla onlara karşı duyulan nefret çok net bir şekilde ifade edilmektedir. Hatta İkinci Haçlı Seferi’nin başarısızlıkla neticelenmesinin bütün yükü de haçlılar tarafından Bizans Devleti'ne yüklenmektedir.

Ancak haçlıların yaşamış oldukları bütün olumsuzlukları Bizans Devleti’ne bağlamak doğru değildir. Çünkü Bizans Devleti’nin sergilemiş olduğu olumsuz bütün davranışların arkasında aslında haçlıların yaratmış oldukları olumsuzlukların izleri bulunmaktadır. Bizans Devleti, haçlıları daha ilk seferde İstanbul surları içine almış ancak haçlılar bu şehirde büyük karışıklıklara sebebiyet vermişlerdi. Aynı zamanda haçlı ordularının ikinci sefer esnasında, güzergâhları üzerinde bulunan şehirlerde yaratmış oldukları huzursuzluklar da onların Bizanslılar tarafından şehir içlerine alınmamalarına sebebiyet vermiştir. Manuel, Türklerle mecburen anlaşma yapmak zorunda kalmıştır. Çünkü, haçlıların nasıl bir tavır sergileyeceğinden emin değildir. Şayet haçlılar Bizans Devletỉne karşı olumsuz bir tutum içerisine girerlerse 
ve bu esnada Bizans Devleti, Türkler ile de mücadele ederse hem doğu hem de batı olmak üzere iki ayrı cephede savaşmak mecburiyetinde kalabilirdi. Yine Bizans Devleti’nin haçlılara vermiş oldukları kılavuzların kaçmasının en önemli sebebi de haçlıların onlara kötü davranması ve sürekli öldürülme korkusu yaşamalarıdır.

Sonuç olarak; ilk seferden itibaren haçlıların Bizans topraklarında yaratmış oldukları karışıklıklar ve ikinci sefer esnasında da aynı hareketleri tekrarlamaları haçlılar ve Bizans Devleti arasındaki ilişkilerin gerginleşmesine sebebiyet vermiştir. Bunun neticesinde de büyük heveslerle başlayan İkinci Haçlı Seferi başarısızlıkla neticelenmiştir. Ancak haçlılar, özellikle ikinci sefer esnasında Bizans Devleti’nin kendilerine karşı olan tavırlarını asla unutmamışlar ve onları kendilerine ihanetle suçlamışlardır. IV. Haçlı Seferi esnasında, haçlıların gözlerini kırpmadan İstanbul'da gerçekleştirmiş oldukları yağma ve katliamın sebeplerini bu ön yargıları göz önünde bulundurduğumuz takdirde daha iyi algılayabiliriz.

\section{KAYNAKÇA}

Alptekin, Coşkun. (1987). "İzmir Türk Beyliği (Çaka Beyliği)”, Tarihte Türk Devletleri, II, Ankara, s.476-480.

Altan, Ebru. (2003). II. Haçlı Seferi (1147-1148), Ankara: TTK, Ankara. Angold, Michael J. (1997). The Byzantine Empire 1025 - 1204; A Political History, New York.

AnnaKomnena. (1996). Alexiad Anadolu'da ve Balkan Yarımadasinda Imparator Aleksios Komnenos Dönemi'nin Tarihi (Malazgirt Sonrası), Çev. Bilge Umar, İstanbul: İnkılap Kitabevi.

Aquensis, Albertus. (2007). Historia Ierosolimitana: History of the Journey to Jerusalem, İngilizce trc. Susan B. Edginton, Oxford: Clarendon Press.

Arslan, İhsan, Süleyman Genç. (2017). “Albertus Aquensis Historia Ierosolimitana Adlı Eserine Göre I. Haçlı Seferi”, Uluslararası Sosyal Araştırmalar Dergisi, X., S.51, s.231-253. 
Ayan, Ergin. (1994). Willermus Tyrensis Historia Rerum in Partibus Transmarin is Gestarum (Denizaşırı Bölgelere Yapılan Seferlerin Tarihi) Adlı Eserinin XVI. XVII. Ve XVIII. Kitaplarının Türkçe Çevirisi), (Yüksek Lisans Tezi), İstanbul.

Ayönü, Yusuf. (2009). “İzmir'de Türk Hâkimiyetinin Başlaması”, Türk Dünyası İncelemeleri Dergisi, C.IX, S.1, İzmir, s.1-8.

Ayönü, Yusuf. (2014). Selçuklular ve Bizans, Ankara: TTK.

Bailly, Auguste. (1970). Bizans Tarihi, II., Çev. Haluk Şaman, İstanbul: Tercüman 1001 Temel Eser.

Baykara, Tuncer. (1974). İzmir Şehri ve Tarih, İzmir: Ege Üniversitesi Matbaasi.

Carnotensis, Fulcherius. (2009). Kudüs Seferi, Çev. İlcan Bihter Barlas, İstanbul: IQ Yayınları.

Charanis, Peter. (1973). "Byzantium the West and the Origin of the First Crusade", Social, Economic and Political Life in the Byzantine Empire, Ed. Peter Charanis, Variorum Reprints, London XIV. bölüm, s.17-36.

Constable, G. (2008). Crusaders and Crusading in the Twelfth Century,Burlington: Ashgate Publishing.

Çalışır, Abdurrahman Onur. (2018). Denizaşırı Ülke'den Havadisler: Haçlıların Mektupları, İstanbul: Kutlu Yayınevi.

Demirkent, Işın. (1994). Urfa Haçlı Kontluğu (1098-1118), II., Ankara: TTK, Ankara.

Demirkent, Işın. (1996).“Haçlılar”, DİA, XIV., İstanbul: Diyanet Vakfı Yayınlar1, s.525-546.

Demirkent, Işın. (1997). Haçlı Seferleri, İstanbul: Dünya Yayınları.

Demirkent, Işın. (1998). "Haçlı Seferlerinin Mâhiyeti ve Başlaması”, Haçı Seferleri ve XI. Asırdan Günümüze Haçl Ruhu Semineri (26-27 Mayıs 1997), Bildiriler, İstanbul s.1-14, 
Duncalf, Frederic. (1969).“The Councils of Piacenza and Clermont”, A History of the Crusades: The First Hundred Years, I, Madison, Milwaukee, London: The University of Wisconsin Press, s.220-222.

Frankopan, Peter. (2012). The First Crusade; The Call From The East, Cambridge: The Belknap Press of Harvard University Press.

Gölgesiz Karaca, Sevtap. (2012). "I. Haçlı Seferi (1096) Öncesinde Bizans İmparatorluğunun Siyasi Durumuna Bakış”, Trakya Üniversitesi Edebiyat Fakültesi Dergisi, 2/4, s.141-153.

Gregory Abu'l-Farac. (1987). Abu'l-Farac Tarihi, Çev. Ömer Rıza Doğrul, Ankara: TTK.

Hill, John Hugh. (1951)."Raymond of Saint Gilles in Urban's Plan of Greek and Latin Friendship", Speculum, S. 2, s.265-276.

Hill, John Hugh. (1953). Laurita Lyttleton Hill, "The Convention of Alexius Comnenus and Raymond of Saint Gilles", The American Historical Review, C. 58, S. 2, s.322-327.

Holt, P.M. (2003). Haçlılar Çağı, Çev. Özden Arıkan, İstanbul: Tarih Vakf1 Yurt Yayınları.

İlgürel, Müçteba. (1993). “Çaka Bey”, İ.A., VIII, İstanbul: İSAM, s.186-188.

Kafesoğlu, İbrahim. (1984). “Selçuklu Çağındaki İzmir Türk Beyinin Adı: Çaka mı, Çağa mı, Çakan mı?” Tarih Dergisi, İstanbul, s.55-60.

Kaleli, Emrullah. (2018). "Bizans ve Haçlı Seferleri”, III. INES Uluslararası Eğitim ve Sosyal Bilimler Kongresi Bildiri Kitabı, Alanya s.1254-1259.

Kanat, Cüneyt\&Devrim Burçak. (2013). Sorularla Haçlı Seferleri, İstanbul: Yeditepe Yayınları.

Kesik, Muharrem. (2003). Türkiye Selçuklu Devleti Tarihi, Ankara: TTK.

Kesik, Muharrem. (2018). Selçukluların Haçlılarla İmtihanı, İstanbul: Timaş Yayınları.

Kırpık, Güray. (2009). "Haçlıların Balkanlar'daki Faaliyetleri ve Tesirleri”, Ekev Akademi Dergisi, Yıl:13, S.39, s.351-362. 
Kırpık, Güray. (2009). Doğunun ve Batının Gözünden Haçlılar, İstanbul: Selenge Yayınları.

Koca, Salim. (2017). "Haçlı Seferleri Sebep ve Sonuçları Bakımından Nasıl Değerlendirilebilir?", Gazi Akademik Bakış, 10/20, s.15-35.

Kotan, Necati. (1974). Türk ve İslam Alemine Karşı Haçlı Seferleri, Adana: Kemal Matbaası.

Lemerle, Paul. (2013). Bizans Tarihi, Çev. Galip Üstün, İstanbul: İletişim Yayınları.

Lilie, Ralph-Johannes. (1993). Byzantium and the Crusader States 10961204 (1994), İngilizce trc. J. C. Morris ve Jean E. Ridings, Oxford: ClarendonPress.

Magdalino, Paul. (1993). The Empire of Manuel I Komnenos: 1143-1180, Cambridge.

Michaud, J.F. (1853). The History of the Crusades, I, New York: Redfield Publishing.

Odo de Deuil. (1948). De Profectione Ludovici VII in Otientem, ing. Çev. Virginia Gingerich Berry, New York.

Oldenburg, Zoe. (1996). The Crusades, İng. Çev. Anne Carter, New York. Ordericus, Vitalis. (1853). The Ecclesiastical History of Englandand Normandy, III., İngilizce trc. Thomas Forester, J. Haddon\& Son Printed, London.

Öğün Bezer, Gülay. (2002). “Zengiler”, Türkler, IV., Ankara: Yeni Türkiye Yayınları, s.803-813.

Phillips, Jonathan. (1996). Defenders of theHoly Land: Relations between the Latin East and the West, 1119-1187, Oxford: ClarendonPress.

Runciman, Steven. (1986). Haçlı Seferleri Tarihi, I, Çev. Fikret Işıltan, Ankara: TTK.

Runciman, Steven. (2002). "Byzantium and the Crusades", The Crusades: The Essential Readings, Ed. Thomas F. Madden, Cornwall: Blackwell Publishing, s.211-220. 
Sevim, Ali, Erdoğan Merçil. (1995). Selçuklu Devletleri Tarihi, Ankara: TTK.

Somerville, Robert. (2011). Pope Urban II's Council of Piacenza : March 1-7, 1095, New York: Oxford UniversityPress.

Thomas F. Madden. (2004). Crusades The Illustrated History, The University of Michigan Press, AnnArbor.

Turan, Osman. (2004). Selçuklular Zamanında Türkiye, İstanbul: Ötüken Neşriyat.

Usta, Aydın. (2016). Çıkarların Gölgesinde Haçlı Seferleri, İstanbul: Yeditepe Yayınları.

Venning, Timothy. (2006). A Chronology of the Byzantine Empire, Palgrave Macmillan.

Virginia G. Berry. (1969). The Second Crusade HC, ed., T.M. Setton ve M.W. Baldwin, I, The University of Wisconsin Press.

Vitalis, Ordericus. (1853). The Ecclesiastical History of Englandand Normandy, İngilizce Çev.Thomas Forester, J. Haddon\& Son Printed, III, London. 